\title{
Context into text into context: marketing practice into theory; marketing theory into practice
}

\section{Structured Abstract}

Purpose - The primary aim of this paper is to explore the dynamics of marketing practice and theory in arguing that much of the dislocation between strategy and practice is due to the inheritance and internalisation of often impractical but persistently dominant, tacit Cartesian assumptions.

Design/methodology/approach - This paper uses case methodology to examine the marketing theory into practice / marketing practice into theory conundrum and explores: their separation (marketing theory and marketing practice); their flows (context to text to context: theory into practice/ practice into theory); their symbiosis (the praxis of marketing); and the dynamic and static (in situ/in aspic) nature of their duality. This work is an exploratory empirical study undertaken in what is a very under-researched area.

Findings - In this paper, marketing theory and marketing practice are recognised as occupying different epistemes. The lifeworld of marketing theorising appears as characterised by a relatively homogenous and mostly cognitive world dominated by rationality and empirical rigour. By contrast, the embodied practitioner inhabits a more highly segmented, fragmented, heterogeneous and frequently improvised landscape.

Practical implications - We propose that the all-consuming clamour for reliance and relevance of theory to practice dictates that the form, function and philosophy of marketing must be co-created in the practical pragmatism of praxis. Praxis is practice informed by theory and theory informed by practice, a cyclical process of experiential, contextual learning.

Originality/value - The paper appears to be the first to bring together Cartesian thought and the practice-theory divide in $\mathrm{B} 2 \mathrm{~B}$ marketing theory.

Keywords: Cartesian thought, Theory-practice divide, B2B marketing, Praxis Paper Type: Case study 


\section{Introduction}

The transfer of knowledge from context to text to context describes the debate about researchinformed practice and practice-informed theory. Whilst the 'theory-practice divide' has been a consistent leitmotiv for some time now, the imperative of 'third stream income'; the general marketization and instrumental re-orientation of Higher Education has injected urgency into the debate. A serious dislocation is evident in the separation between theory and practice; between strategy and implementation, and academia and practitioner logics. Furthermore, the voices describing this gap as a gulf are becoming louder, with some claiming that it "has become detrimental to long-term health of the field" (Reibstein et al, 2009, p. 1). Others assert that the divide should be even wider because actors and academics "approach different goals and strive for different metrics" (Piercy, 2010, p. 13, cited in Lee and Greenley (2010)). Ardley and Quinn (2014, p. 97) argue that "production and consumption of marketing theories are subject to two different technologies and processes that are not always mutually compatible". Baker and Holt (2004, p. 564) argue that there should be a closer integration of marketing theory and practice in order to prevent marketing from becoming marginalised. Wilkinson and Gray (2007, p. 39) posit that the locus of the theory applicability problem is in the "discrepancies that exist in the supply and demand of marketing theories" as production and consumption are predicated on different technologies and processes. Marketing theory can too often fail to recognise the diversity of marketing practice. The manifestation of marketing knowledge in thought, word and deed - or theory, published paper or marketing plan - is evident in "the micro-discourses and narratives that marketing actors draw upon to represent their work" (Ardley and Quinn, 2014, p. 97). An examination of these micro discourses offers an opportunity to consider these divergent perspectives.

We argue that theorising often occupies an abstract world of retrospective, disembodied, 'dead', analytical autopsies whereas the practical world is one of a present, concrete, 'lived', holistic synthesis (of 'coming together'). The two worlds appear separated 
by different logics: theoretical, strategic analysis being privileged and discrete; the unscientific world of practice being denigrated under the persistent influence of the Cartesian separation of mind and body. We argue that praxis attempts to reconcile the two. It is "a synthetic product of the dialectic between theory and practice" (Heilman, 2003, p. 274). Praxis and theory occupy different domains that overlap partially and intermittently where praxis is a site where embodied action/experience and reasoning (an amalgam of practical logic and objective theorizing) unfolds through language and discourse. Information is interpreted differently according to how the interpreters see themselves and others so realities are therefore characterised by multiple experiences, multiple discourses (polyphony) and multiple ideas. It is only the multiple discourses that are public, most of the multiple experiences and polyvalent ideas are private and inaccessible. Polyphonic discourses are the visible stage upon which multiple words are enacted- we are forced to infer and interpret the rest of the complexities through ethnographies of praxis. Ethnography is therefore the most appropriate methodology to examine routine embodied practices and the associated use of objects and mental schemata between embodied subjects as identities who play their identity games to maintain and enhance positions (Rasche and Chia, 2009).

From this viewpoint, we use the analogy of practice as a multiple stage where theory is an aspect of the script 1) that is known and believed by some characters who mostly follow it, 2) known yet not completely believed by others who choose instead to selectively alternate between improvising and following the script, and 3) completely unknown by others who make it up as they go along; improvising in the moment without any reference to 'the script'. Triana (2009), for example, accuses management academics in their relationship with business of 'lecturing birds on flying'. Until some kind of mutually satisfactory bridge between theory and practice is forged, we argue the two will never achieve adequate coordination. The implication is that the problem does not lie in implementation but mainly in the impracticality of theory in its captivation by the disembodied, abstract 'dead maps' of 
scientism (Schumacher, 1977) and its cloaking of situated, practical logic with generalised or universal Cartesian dualistic representations. Cartesian worldviews cultivate truth correspondence by contrast to practical truth, which is always in context, in the moment and in action. The separation gap is somewhere in the spaces between rigidity in aspic and dynamism in situ, between rigour and relevance, theory and practice, and between $a$ posteriori and a priori knowledge.

\section{The Cartesian cloak of abstract concepts and analytic rationality}

According to Foucault (1970, p. 66), "there is always only one 'episteme' that defines the conditions of possibility of all knowledge, whether expressed in theory or silently invested in practice". Since the 1870 s, management discourse has alternated in dualistic switching between rationalist and normative rhetorics of control (Barley and Kunda, 1992), where marketing theories have been locked into a constant ideological alternator between mechanistic and organic solidarity. This suggests that marketing theory is stuck in repetitive ideology-counter ideology cycles. The consequence is that it is the Cartesian 'grand theories', meta-narratives and strategic frameworks, whether sanctioned by current management discourse fashion or not, that are the problem rather than some operational deficiency in their implementation. Grand theories and strategic frameworks bear homage to Cartesian influences either tacitly or explicitly and, because of this, are not wholly implementable since their logic is alien to the embodied and pragmatic, polyvalent realities, discourses and cognitive style of the practitioners and operational managers who would have to implement them. A Cartesian 'fallacy of detachment' between theoretical and practical perspectives causes a comprehensive set of problems in understanding and representing practical lifeworlds in academic discourse and to the virtual impossibilities of implementing nomothetic grand theories and strategic frameworks in practice. They ignore and disconnect from any 
practical logic involving meaningful, situated realities accessed directly through experience (Sandberg and Tsoukas, 2011).

One of the legacies of Descartes is the metaphor of 'Knowing as Seeing' (Lakoff and Johnson, 1999) and the privilege afforded to rational, individual thought (Braudel, 1973). Thus knowledge is analogically framed as a viewpoint. The Cartesian world is a 'picturable' collection of separate, objective elements in motion according to laws discoverable through rigorous scientific methodologies (Shotter, 2008). This leads to the Cartesian mind, metaphorically 'seen' as a camera-like container able to picture ideas as objects through the light of Reason. Non-rational 'views' are those which, to continue the metaphor, leave us in the dark and out of the picture. Combined with Newton's empirical observation, induction and deduction and hypothesis testing to afford general laws, the scene was set for the escalation of a scientific panacea as the hegemonic episteme. Cartesian 'pictures' are transmitted through both discourse and thought. Since Descartes, and the beginning of the inception of scientific management, the dominant Western modernist style of understanding the world has been an entitative, essentialist and (sometimes called 'logocentric') still, representational picturing. Truth, within this worldview of Western Enlightenment philosophy, is universal and assumed as 'found' through rational, ontic knowledge as opposed to 'made' through experiential, phenomenological understanding. This is at odds with the practitioner perspective where meaning is created, controlled and interpreted culturally and economically in situ.

Part of the Cartesian delusion is the belief that knowledge and truth are discovered through rational analysis based on fixed, universal causal factors and that an "objective world 'out there', is perceived as different from the subjective world 'in here' " (Magala, 2005, p. 9) without acknowledging that the words and numbers being used are themselves causations. This has resulted in grand theories and strategic frameworks that fail to get implemented only to be rapidly replaced by new fashions of rational Truth. Academics and strategic managers 
adopting this worldview detach and separate into an inner conceptual and abstract world where they can only communicate with themselves and are fearful of the uncertainties apparent in the world of practical experience. Polonsky and Whitelaw (2005, p. 198) claim that academic institutions globally encourage publication in the most prestigious journals to the detriment of influencing practice: "Prestige first; contribution to theory, second; and contribution to practice and teaching, a poor third and fourth". The 'messy', rationallybounded, intuitive, indeterminate, improvised and heterogeneous 'moving picture' realities of the practitioner are abandoned for neater, homogenous, rational/logical, static pictures that afford more certainty and potential for understanding and control.

In examining the 'living experience' of the practitioner, abstract scholarly theories are problematic with one issue being the rigour/relevance dichotomy. There has been a tendency to conceal the 'raw and naked', embodied 'living' experience of practice in a Cartesian cloak of abstract concepts and analytic rationality. This 'cloak of impenetrable rigour' (Lee and Greenley, 2010, p. 17) covers many things unsuitable for the purposes of the audiences of scholars, who usually expect abstract conceptualisations, clothed in reasoned explanations and 'rigorously tested' theories to justify their attention and legitimate approval. Being caught in a "research-education-practice triad" is the attempted balancing between inductive "letting reality tell its story" and deductive "squeeze reality into preconceived theory" favoured in education and social science research (Lee and Greenley, 2010, p. 7) where naturally-occurring narratives are often obscured by the need for reason and rigour. Much of the dislocation between strategy and practice is due to the inheritance and internalisation of Cartesian assumptions and the contemporary discourses that transport them. We view these Cartesian assumptions as 'memes' which result from their saturation of Western embodied, discursive and cognitive aspects of being. The rigidity of Cartesian assumptions is inclined to produce separation not symbiosis, competition not complementarity and monologues not dialogues. As academics, we are subject to these assumptions and often cling to our 
purportedly objective, scientific template 'like traumatised survivors of a shipwreck' (Brown, 2010, p. 98), via inward, intellectual self-absorption where research and reflexivity often lead to involution not evolution. This is echoed in Hackley's (2009) description of Marketing as a bifurcated 'schizophrenia' between intense paradigm warring academic tribes and naïve populist, 'off the shelf', managerialist, quick-fixes. Consequently, this paper will examine the often incommensurable and incompatible narratives of the separated parties to evaluate the increasing disconnect between marketing theory and marketing practice. In examining this rift, this paper seeks to question the relevance of marketing in aspic and provides in situ evidence where scholars and managers have employed a legitimate transfer of knowledge from context to text to context.

\section{Competing epistemes and divergent discourses}

Charged with implementing a rational, strategic plan, the practitioner knows from experience why and where it won't work. In many cases, she will implement those aspects of the plan that can be made to work differently in different contexts. What works in a logico-scientific culture will invariably be attributed to the rational strategic plan and what doesn't will likely be attributed to the practitioners' incapacity to comprehend it. Hackley and Skålén (2011, p. 190) advocate a "stronger focus on marketing-as-practice" (MAP) in marketing in order to engage with critical perspectives and open up a mutually enriching dialogue between MAP and the more established strain of practice research. Similarly, Chakrabarti et al. (2013) employ a network-as-practice perspective (NPP) in looking at performative aspects of an exchange system. Codified marketing knowledge, like any other form of practical knowledge, has a relation to professional practice which is not necessarily reflective of the cognitive style of 'experts' within its domain (Hackley, 2009). It is the "relationship between codified marketing theory and practical strategic marketing expertise" (Hackley, 1999, p. 720), particularly ineffable and unarticulated knowledge, which is the challenge for research. 
Translating this tacit practitioner knowledge into the empirical domain of the academic business community and making it pedagogically appropriate is high on the emerging $\mathrm{HE}$ agenda of value and vocation in the UK. It is therefore proposed that the underpinning theoretical foundations of this work will be a critical and normative discourse-analytic approach, particularly in its examination of socio-cultural approaches to actions and power projected through these various discourses (Schiffrin et al., 2001).

Lowe et al. (2005, p. 198) claim that marketing studies often legitimise an 'amoral scientism' as the guiding principle of marketing practice and propose that conventional paradigms are symptomatic of an epistemological trap that privileges knowledge to the detriment of other vital virtues such as practical wisdom or phronesis. Scott $(2007$, p. 7) accuses marketing studies as reinforcing a "relatively homogenous and uncritical business school agenda". Part of the "practice-into-theory' challenge is what it is to be "an expert at marketing management and strategic levels of decision making, and how might theory in marketing model this expertise in such a way as to promote its acquisition" (Hackley, 1999, p. 735). This has implications for both the practice and teaching of marketing. The theorypractice conundrum polarises those that claim research can offer managerially useful insights (Elliott and Jankell-Elliott, 2003) and those like Holbrook (1985) and Cayla and Eckhardt (2007) who claim that research is an end in itself and may not be directed at practitioners. Cornelissen (2002) describes this as directed at fundamental understanding per se rather than understanding for use (by managers). The hegemony of rationalistic discourse is slowly shifting in that the strongly institutionalised strategic managerial marketing imperative is being questioned by an increasingly societal, co-creative force. Of the many marketing constituencies, the dominant discourse may be with the academy, but the hegemony is gravitating towards recognition of contextual marketing meaning. The long-established paradigm which shapes the planning and teaching of Marketing is under threat from both an academic point of view and the contextual practitioner world of ad hoc application. 


\section{The practical world of raw and naked experience}

The practical world is characterised by a dynamic instantaneity of action, a producer /consumer simultaneity of interaction and an imperative of contextual co-creation. Most engagement of practitioners within this world is initially through market-place intuition, sensory perception, emotion and other embodied, corporeal or visceral reactions, which are not (yet) rational. The practitioner relies mostly upon the heuristics of contextual engagement learned from experience or what may be termed the pragmatism of praxis, or perhaps, the praxis of pragmatism. Unlike other fields of scientific enquiry, marketing is much more context-dependent (Sheth and Sisodia, 1999). The practical world is not linear and mechanistic because it is made up of tangled webs of meaning, connected but untraceable relationships and ubiquitous speculations, abductions, 'antenarratives' (or speculative guessing-games, incomplete or proto-stories), tacit imagery, indirect and analogical symbolism and non-logical confusions, misunderstandings, misrepresentations, half-truths and lies (Boje, 2008). This antenarrative world is one where the practitioner inhabits the pandemonium of emergent, fragmented and largely incoherent multiple realities requiring heuristic improvisation of situated events where there is in practice, little time for strategy in its classical sense.

Making adequate sense of this complexity requires an initial understanding of embodied, perceptual experience involving discourse (language, communication, power/knowledge), which includes mostly abductive and analogical reasoning, semiotic projections and symbolic imagery in stories, narratives, antenarratives and metaphors. Whereas written plans and rational analysis are explicitly expressed, the 'lived' knowledge of pragmatic praxis is more often tacit, mostly non-rational and sometimes irrational. Reasoned and logical post hoc explanations and rational legitimations may eventually be developed by practitioners but invariably the chaos of change and new, unexpected events in the moment 
means that these logical explanations are unlikely to 'hold' for very long as dynamic change and new embodied reactions and discourses disable their practical relevance.

Understanding the practical world requires an appreciation that it is polyvalent and fragmented, 'polyphonic' or many voiced, dealt with mostly through a 'felt sense' of immediate, practical, corporeal perceptions and pragmatic interactions moving from one context to another. Sense-making in this domain more often involves 'phronesis'; practical intuitive, emotional, corporeal engagement with experience. Here, the embodied, heuristic ability of intuition is privileged over rational, logical evaluations (Patterson et al., 2012) most of the time and in most contexts. Practical problems are dealt with in the moment in a bricolaged and pragmatic fashion as practitioners employ their habitus and use what is ready to hand to move onto the next issue, meeting or day. Practical, pragmatic wisdom, which derives from experience, dictates that practical actors heuristically change what they believe, how they 'view' and talk about their situation in order to improve it. 'Strategy' is often created ad hoc and in situ, adopting scientific and rational analysis and solutions but selectively adapted to conform with the experience and working practice; more an Aristotelian 'practical philosophy' of common-sense enquiry than applied science.

\section{Research context and methodology}

The primary aim of this paper is to explore the dynamics of marketing practice and theory where the empirical evidence supports our theoretical position as a starting point for other researchers to develop in future empirical investigation. There are, therefore, tight parameters to outline: at this exploratory stage it was deemed necessary to investigate three specific case studies that demonstrate and recognize the complexity and ambiguity of how marketing theory and practice ebbs and flows between these two distinct spheres. Indeed, these cases tend to reflect research problems in the interpretivist paradigm (Perry et al., 1999). As we will see, the appropriateness of using 'contextual' case-study research is particularly germane 
in applying the theoretical position to practical business situations: embedded in dynamic conditions, where decisions are often made in the moment, where this in-situ context demands immediacy, and, where the boundaries of business functions and activities often merge into a holistic system (Yin, 1994). There are many commentators regarding the use of case studies in research. On the one hand, case study can be assumed to be limited and anecdotal, criticised as 'mindless empiricism' (Adams and White, 1994: 573). On the other, as is the case in this paper, 'case-study research provides the researcher with an input of realworld data from which concepts can be formed'. Moreover 'marketing educators use cases as illustrators and examples... to make general concepts more tangible' (Gummesson, 2001, p. 35). It has been established that there are no ideal number of cases (Yin, 1994), although it is advocated there should be a minimum of two (Eisenhardt, 1989). It is important to note, the 'case study' approach provides a strategic overview to the study. However, the research could be most aligned with the characterisations of an ethnographic 'case-worker' (Stake, 2005), set within three distinct case contexts. This paper sets the empirical field in the participants' natural working environment, which included 10 participating practitioners.

The ethnographic surge is becoming more widespread in Marketing (Brown, 1995; Brownlie, 1997), effectively holding ground in consumer marketing research, and now expanding into business to business marketing (Borghini et al, 2006, p. 1151). The value of ethnography to the research is embodied by its appropriateness of being "close to reality, providing depth of understanding" (Carson et al, 2005, p. 149). The research benefited from engagement with literature offering rigorous methodological benchmarks in the area of marketing (Goulding, 2005; Gummesson, 2001), recognizing that the research should be conducted over a long period, in-situ and make use of a number of sources of data, such as documents, observation and depth interviews. Data collection was essentially ongoing, as we became more familiar with the context and informants, justified to be a feeling rather that a prescriptive representation: "Ethnographic practice is more like feeling your way than 
following a recipe... sampling is related to the extent to which research is representative of other groups, or types of people" (O'Reily, 2012, p. 45). This recipe was informed by a diverse range of roles, level of strategic significance to the business and how that role interconnected with the marketing function in some way (Bryman, 2012; Patton, 1990). The sampling selection was informed by prior theory based on the case context that illustrated various 'actor' orientations such as 'naïve practitioner' and 'pracademic' (Wilkinson and Gray, 2007, p. 50). Hence, Emerson et al (1995, p. 237) recognise that 'ethnographic research and analysis are both deductive and inductive at the same time'. In ethnography, research questions and analysis are informed by the theorising of others, 'therefore, in some ways you are deducing what you might suspect... in this way you are practicing a sort of deductive method or process (Murchison, 2010, p. 190). Significantly, however, within this paper, ethnography was employed as an inductive process, particularly in allowing insights to emerge through an iterative process of data analysis.

The empirical evidence derives from ethnographic research conducted with 10 senior managers in various roles that are connected in some way to the marketing function. The data collection was conducted over a two year period using depth interviews and participant observation and is presented in the form of case study vignettes, which have been analysed and embedded in the theoretical premise of the paper. Each case takes a contextual narrative approach featuring each participant in the context of a particular orientation: namely academic, consultant or practitioner. This method of data analysis accords with Fischer's, (2011, p. 158) recommendation of "constructing vignettes to test theoretical themes against data", a proven method in supporting qualitative research in psychology. The case vignettes are only intended to illustrate the theoretical discussion in a form that tackles the issue raised by Scheer [cited in Lee and Greenley (2010, p. 9)] in asserting a significant issue in communicating between the two spheres "There is no reason why strong, effective, theorydriven research cannot be communicated in clear terms to practitioners... the research is 
managerially useful, but the authors' efforts to communicate are so laden with 'researchese' and methodo-academic jargon that it is unintelligible to the vast majority of practitioners" moreover "this can be remedied by co-authoring with a "bilingual" colleague who can translate the research using terms and examples that can be clearly understood by managers and executives" (Lee and Greenley, 2010, p. 9).

The analysis of the ethnographic data was underpinned by methodological benchmarks (Goulding, 2005), which involved a process of identifying and interpreting patterns in data (e.g. interview transcripts, other textual evidence like business reports, observation notes and research memos etc.) in order to construct a holistic story that is embedded in-situ. This involved synthesis, by coding and content analysis where the above data is pooled so that a thick description, or "ethnographic analysis is presented as informants' stories and case studies" (Boyle, 1994, p. 158). Hence, the data is presented as a narrative, where research is concerned with the ways "in which social actors produce, represent and contextualise experiences through narratives" (Coffey and Atkinson, 1996, p. 54). Therefore, the narratives are framed around the central characters in the coming vignettes, the benefit of narratives is two-fold: (1) they allow the research to remain embedded in the context, informed by the various sources of data but present a cogent story "by presenting research as a story we can avoid the fragmentation that is inevitable when we break down a statement into concepts and categories" (Gummesson, 2001, p. 38); (2) analysing and presenting research as stories is flexible, and can be exciting, as marketing academics we must communicate our findings in engaging ways, as Peter Drucker notes "it is only in the last twenty or thirty years that being incomprehensible has become a virtue in academia" (1987, p. 11).

The duration of the fieldwork was two years, covering a total of 65 researcher-days of field experience. Data collection included observation of 'in-situ' interactions, in order to identify and structure patterns so that meaning could be interpreted. Significantly, these in- 
situ interactions covered formal meetings at certain periods of fieldwork such as project milestones (e.g. board development meetings or conceptual meetings with clients). In other words, fieldwork covered formal and casual interactions with various different types of actors, in many different venues. Textual data was gathered from 30 interviews, of various lengths and types, including formal depth interviews, meetings and casual, informal 'catchups'. Highlighting the value ethnography can add, these observations were found to support the validation process of interpreting textual data from interviews, triangulated with casual discussions and field notes, as well as many different forms of business reports, or 'artefacts' (Goulding, 2005).

\section{Results}

Context into text into context: The empiricism of the practitioner; the rationality of the academic.

According to Zinkham and Hirscheim (1992, p. 83), "conventional philosophical wisdom holds that knowledge is not infallible but conditional; it is societal convention and is relative to both time and place". In addition, some commentators have pointed out the "surprising paucity of instances in which academic research in marketing has resulted in widespread change in business practice" (Sheth and Sisodia, 1999, p. 84). The nature of marketing knowledge is that it can be generated both by the empiricism of the marketplace - the dynamic experiential in situ and ad hoc praxis - as well as scientifically deduced - post hoc, considered rationality. The flow can be either way; practice to theory or theory to practice. This context to text to context phenomenon is an iterative process of re-cycling and reinvention; the exact nature of knowledge transfer is that the flow can be symbiotic yet intertwined. Figure 1 below shows this iterative process and illustrates the flow, separation and connectedness of the key actors in marketing knowledge production and consumption. The empirical evidence of marketing theory to practice/ marketing practice to theory flow is 
highlighted in the following results sections using vignettes, which illustrate three types of case study:

- Type A: Academic Orientation: Typical examples are the transfer of knowledge from University to KTP in a quasi-consultative capacity in B2B consultative exercise in the Public Sector.

- Type B: Practitioner Orientation: an example from a senior Director in a global construction plc.

- Type C: Hybrid Orientation: Private sector application of theory into practice from a senior manager in a global banking corporation.

\section{Insert Figure 1 about here}

A narrative description of each case study 'type' is given in each section in order to illustrate the variance in data informants and the respective research environments from which the data was collected. For guidance, these findings are then illustrated in the form of vignettes and associated researcher notes. This is consistent with how the data findings are presented, amalgamated from all participants, but framed around three main characters who feature in the vignette narratives: 'Dave' 'Kate' and 'Kevin'. In particular, the use of researcher field notes taken within the context of each individual case, enhanced clarity of data collection and analysis. They are organised into the 'orientation' following the same 'characters' outlined above, which highlight the use of 'thick description' (Geertz, 1973) in a strong ethnographic account in marketing (Goulding, 2005). It is important to reiterate that the principal empirical aim was to undertake an exploratory study to demonstrate how theoretical assumptions can be contextualised in a dynamic in-situ context, allowing future studies to advance research potentially using the following orientations: 


\section{Type A Case Study: Academic Orientation}

Dave was a consultant and academic that worked from a number of sites, including his office at his academic institute and ten working consultant days on site at the client's base. Thus the empirical field was spread across a number geographic, or 'spatial' dimensions (Boyle, 1994). The point is that, Dave operated across two worlds, practitioner and academic; therefore, it was essential for the researcher to immerse himself in these distinct spheres to gain a richer understanding of processes, dynamics and interactions, between the client, stakeholders, research assistants and academic colleagues - all of which were involved and connected to the project in some form or another, as a form of community of practice (Goulding, et al., 2010). The data informant was mid-30s and had worked in several industries in various senior-marketing roles, most principally consultancy in financial and tourism sectors. From the academic perspective, he is what could be termed an 'earlyresearcher' in that he has a good grasp and experience of navigating between the theory and practice spheres, but was still developing his professional academic credentials.

\section{Insert Figure 2 about here}

\section{Insert Figure 3 about here}

\section{Academic Orientation Discussion}

It is clear from the empirical evidence presented in Figures 2 and 3 that Dave had knowledge of the key principles that govern these worlds, the language used and, most importantly, the metrics of success. Essentially, if we view the data narrative as a whole, it is clear that Dave has a good grasp of the existence of those two spheres and that they are governed by different principles. These principles also have distinct metrics of success, whether it is capital funding or academic outputs. One could argue that, in this case, Dave is using his awareness of the theory-practice divide as both a reality and an opportunity. This echoes Lee and Greenley's 
(2010) observation that academics and executives can gain important benefits through collaboration and partnering: "Marketing theory cannot develop in the abstract. Academics need access to business and organisational environment" (p. 13). Dave, who is 'bi-lingual' in both spheres, appreciated the existence of opposing drivers of publications and profit but argues passionately that 'We do not always have to cross the divide'. The success metrics of this project in both academic and practitioner outcomes, suggest, he may be right, in this context.

\section{Type B Case Study: Hybrid Orientation}

It was essential for the researcher to immerse himself in these distinct spheres to gain a richer understanding of processes, dynamics and interactions, between the client, stakeholders, research assistants and academic colleagues - all of which were involved and connected to the project in some form or another, as a form of community of practice (Goulding, et al., 2010).

Similarly, these principles underpinned the empirical fields for Kate's and Kevin's days on site in their corporate working environment. Access for Kate was slightly restricted in terms of days on site, but the ethnographer was allowed to view Kate during her MBA dissertation group and supervisors meetings, therefore covered dimensions of 'in-situ' observation. This unique access provided an excellent insight into the way she interacted with theory and how that influenced behaviour and attitudes in practice; what could be termed her emerging academic exposure.

Figure 4 (below) presents the narrative data for the 'Hybrid Orientation':

Insert Figure 4 about here

Insert Figure 5 about here 
Similarly, the themes of principles (and key drivers), language and metrics of success were again present in the data. Kate also viewed being able to apply theory in situ as advantageous. Having worked as a consultant in a digital agency, allied to the dynamic nature of her current role, the ability to navigate both worlds was often very beneficial. This was very evident in the outputs needed: providing a practical dynamism in the context of commerciality rather than manifest in published outputs. It is clear from her research memo that language was inherently linked to the way in which she attained credibility of making the abstract 'theory' relevant to her role and career. In fact, the data evidence demonstrated that, based on her personal success of converting academic currency into commercial capital, she had now successfully embedded that practice into her team. She characterised as an iterative process, the very essence of what is postulated in this paper. She had identified that she was an influencing factor in bringing theory into practice, by using her team to apply the most germane aspects (from her guidance). She cited how her team had used personas to disseminate an academic term/process to an often, cynical, non-academic functions across the business. The merit of this approach was evident in Kate's ability to translate the abstract into a language of delivery. This chimes with Scheer's comment (cited in Lee and Greenley, 2010) that "the research does not deal with such minutiae that managers will find it ridiculous" (p. 9). In many ways, Kate is continually being successful in the practice-intotheory challenge, by embedding her orientation into practice through her team, where it is having significant impact at strategic levels of the business (Hackley, 1999) by offering research that offer managerial useful insights (Elliott and Jankell-Elliott, 2003).

\section{Type C Case Study: Practitioner Orientation}

The empirical field for Kevin was very similar to Kate's in that a number of observational days were spent in the corporate offices, but differed such that Kevin allowed access into his home working office. Hence, this supports the proposition of the paper in 'understanding the 
phenomenon as it occurs in situ' (Belk et al., 1989, p. 3), but across different 'spatial' dimensions, work, home and study. Indeed, each case context highlights how the researcher was 'able to see the world (at least to some extent) in the same way as the informants and to establish an empathetic relationship with the' Borghini et al., 2006, p. 1153).

\section{Insert Figure 6 about here}

\section{Insert Figure 7 about here}

\section{Practitioner-Orientation Discussion}

The evidence cited in Figures 6 and 7 clearly demonstrate both Kevin's grasp of the principles that underpin academic endeavours, as well as his ability (through his own

personal experiences), to balance sometimes stilted, detached rational analysis. Here again the principles of the spheres are called into question: academic institutions target the prestigious journals, prioritising contribution to theory in the first instance; pragmatic impact is often somewhat down the list of priorities (Polonsky and Whitelaw, 2005). Kevin isn't consciously detaching his practice from the world of theory; it is a matter of principal survival in the crux of commerciality. This vignette demonstrates the intuitive know-how gained in-situ is often applied intuitively rather than relying on abstract theories. As Kevin acknowledges, critical management theory has influenced his career but often not at the crucial moment of the decision-making.

\section{Overall Perspective}

In summary, these cases illustrate the fact that a practitioner's life is a tough and complex one and cannot be neatly arranged into isolated issues (Ardley and Quinn, 2014; Wilkinson and Gray, 2007). The data suggests that working towards a polyphonic discourse of marketing, which often overlaps into different business functions and priorities is imperative. Whilst 
Kate is a good example of 'bridging the divide', there is a need to nurture a climate for 'engaged scholars' like her (Van de Ven and Johnson, 2006). Dave's example demonstrates the need to acknowledge the discrepancies between practice and academia, operating with institutional constraints (Wilkinson and Gray, 2007), these agendas are not going to go away - nor should they - but they demand further exploration. Marketing Academics have very distinct cognitive and social norms guiding them, adopting protocols to work through problems akin to their disciplines. These are often delivered by individual academics or homogenous teams of academics, sharing similar goals that may include formalised research outputs (Salipante and Aram, 2003). In contrast, 'fit-for-purpose', theory ready to be applied tends not to emerge in marketing practice. Instead, the process is more inductive, formed insitu, dynamically responding to the heterogeneous contexts, driven by "specific projects, processes, functions or applications and their intended uses" (Wilkinson and Gray, 2007, p. 41). In the Construction Industry example, we saw that the formation of knowledge in situ relies mostly upon the contextual learning specific to the sector, with experience layered year after year. Collins (2001) recognizes this tacit knowledge, often concealed and elusive, is formed in the mastery of practice, or we suggest, in the crucible of commercial immediacy. Kevin's evidence reaffirms how the praxis of pragmatism, overrides the challenge of theory, whereby tacit knowledge, ambiguous, and governed by subjective attitudes contextually formed is the actual driving factors in decision making (Patterson et al., 2012).

\section{Concluding comments}

\section{A practice-theory bridge}

We advocate that a practice-theory bridge would require a rather more 'bottom up' approach set based upon beginning with due attention to practical concerns, embodied perceptions, discursive abductions and theorizing relevant to effective local, situated and contextual implementation. This is an agenda that would seek situated, dialogical and 'polyphonic' 
(many-voiced) approaches to local and particular practical marketing contexts. The new bridge, quite clearly, in order to support both rational and practical logics would have to be a polymer made of the material of both Reason and practical logic - of theory and practice. A purely rational, scholastic view, which privileges reason and diminishes praxis, is untenable as a bridge (Splitter and Seidl, 2011) which to be viable would have to incorporate multiple logics. Furthering multidisciplinary theoretical developments in marketing requires a 'territorial expansion' of marketing to incorporate, prioritise and centralise marketing practice (promoting greater involvement of non-academic audiences), reflexivity and introspection (Shankar, 2009). There are implications for the academic marketing community in that mutual referencing academic syndicates or inter-referencing 'influence networks', as described by Armstrong and Lilley (2008) would have to be regarded as a form of bridgeblocking. In proposing an alternative that advocates newer and more heterogeneous approaches we propose that 'top down' Cartesian-inspired nomothetic theories have not worked operationally and imply that they are never likely to work because they are inclined to abandon from the outset any practical concerns. The criteria for 'bridge design' should also, in our view, be based upon which approaches most successfully retain the benefits but avoid the limitations of scientific rationality and accomplish contributions with 'theoretical prescience' in order to best engage with practical logic (Corley and Gioia, 2011). For example, in UK Higher Education, an 'impact' agenda is a clarion call for such bridgebuilding relevance and applicability. The bridge to facilitate crossing this difference requires a something that can sustain loads on both the strategic and practice sides of the gap.

Marketing often gets lost in metaphors and markets; principles and practice are often protected by principle and praxis. The all-pervasive nature of marketing as a transforming cultural phenomenon, a managerial ideology, and an indispensable academic imperative, has made the discipline vulnerable to both external and destructive debate with regard to its aims, values, predominant theories and methods (Levy, 2003). The most pressing concern within 
the marketing discipline has been disconnect between theory and practice. Katsikeas et al. (2004, p. 568) take the view that "rigorous research conducted on issues relevant to practising managers is especially valuable for the marketing discipline's future development and status". They posit that marketing education is in the hands of four constituent players: academics, teachers, consultants and practitioners. Although Gummesson (2000) acknowledges there is a difference between academics and consultants, he also recognises the commonality in that the consultant pecks at theory and contributes to practice, while the academic pecks at practice and contributes to theory. Praxis is "the struggle to link theory to practice, action and reflection in order to bring about transformation" (Humm, 1995, p. 2). Ardley and Quinn (2014) emphasise that bridging the marketing-practice disconnect is problematic to pursue, and harder to achieve. They suggest 'a more fruitful agenda resides in the development of a polyphonic and creative micro-discourses....that essentially champions... context, difference and individual meaning in marketing knowledge production. 


\section{References}

Adams, G. and White, J. (1994), "Dissertation research in public administration and cognate fields: An assessment of methods and quality", Public Administration Review, Vol. 54 No. 6, pp. 565-76.

Ardley, B.C. and Quinn, L. (2014), "Practitioner accounts and knowledge production: An analysis of three marketing discourses”, Marketing Theory, Vol. 14 No. 1, pp. 97-118.

Armstrong, P. and Lilley, S. (2008), "Practical criticism and the social sciences of management”, Ephemera, Vol. 8 No. 4, pp. 353-70.

Baker, S. and Holt, S. (2004), "Making marketers accountable: A failure of marketing education”, Marketing Intelligence and Planning, Vol. 22 No. 5, pp. 557-67.

Barley, S.R. and Kunda, G. (1992), "Design and devotion: Surges of rational and normative ideologies of control in managerial discourse", Administrative Science Quarterly, Vol. 37 No. 3, pp. 363-99.

Belk, R.W., Wallendorf, M. and Sherry, J.F. (1989), “The sacred and the profane in consumer behaviour: Theodicy on the odyssey", Journal of Consumer Research, Vol. 16, pp. 137.

Boje, D.A. (2008), Storytelling Organizations, Sage Publications, London. 
Borghini, S., Golfetto, F. and Rinallo, D. (2006), “Ongoing search among industrial buyers”, Journal of Business Research, Vol. 59 No. 4, pp. 1151-59.

Boyle, J.S. (1994), "Styles of ethnography", in Morse, J.M. (Ed.), Critical Issues in Qualitative Research Methods, Sage, Thousand Oaks, CA.

Braudel, F. (1973), The Mediterranean and the Mediterranean World in the Age of Phillip II. 2 Vols. Trans. S. Reynolds, Collins, London.

Brown, S. (1995), Post-modern Marketing, Routledge, London.

Brown, S. (2010), “The theory-practice divide: Thoughts from the editors and senior advisory board of EJM”, European Journal of Marketing, Vol. 44 No. 1/2, pp. 5-20.

Brownlie, D. (1997), "Beyond ethnography: Towards writerly accounts of organising in marketing”, European Journal of Marketing, Vol. 31 No. 3/4, pp. 263-82.

Bryman, A. (2012), Social Research Methods, Oxford University Press.

Carson, D., Gilmore, A., Perry, P. and Gronhaug, K. (2005), Qualitative Marketing Research, SAGE Publications

Cayla, J. and Eckhardt, G.M. (2007), “Asian brands without borders: Regional opportunities and challenges", International Marketing Review, Vol. 24 No. 4, pp. 444-56. 
Chakrabarti, R., Ramos, C. and Henneberg, S. (2013), "Network dynamics in the UK pharmaceutical network - A network-as-practice perspective”, Industrial Marketing Management, Vol. 42 No. 3, 356-71.

Chia, R. (2004), "Strategy-as-practice: Reflections on the research agenda", European Management Review, Vol. 1, pp. 29-34.

Coffey, A. and Atkinson, P. (1996), Making Sense of Qualitative Data, Thousand Oaks, CA: Sage.

Collins, H.M. (2001), "What is tacit knowledge?", in Schatzki, T. R., Knorr Cetina, K. and Von Savigny, E. (Eds.), The Practice Turn in Contemporary Theory, Routledge, Abingdon, U.K., pp. 107-19.

Corley, K.G. and Gioia, D.A. (2011), "Building theory about theory building: What constitutes a theoretical contribution?", Academy of Management Review, Vol. 36 No. 1, pp. 12-32.

Cornelissen, J. (2002), “Academic and practitioner theories of marketing”, Marketing Theory, Vol. 2 No. 1, pp. 133-43.

Drucker, P. (1987), The Frontiers of Management, London: Heinemann.

Eisenhardt, K.M. (1989), "Building theories from case studies research", Academy of Management Review, Vol. 14 No. 4), pp. 532-50. 
Elliott, R. and Jankell-Elliott, N. (2003), “Using ethnography in strategic consumer research”, Qualitative Research: An International Journal, Vol. 6 No. 4, pp. 215-23.

Emerson, R.M., Fretz, I. R., and Shaw, L.L. (1995), Writing Ethnographic Fieldnotes, Chicago: University Press.

Fischer, T.C. (2011), Qualitative Research Methods for Psychologists: Introduction through Empirical Studies, Academic Press: London.

Foucault, M. (1970), The Order of Things: An Archaeology of the Human Sciences, London: Tavistock Publications Ltd.

Geertz, C. (1973), "Thick description: Toward an interpretive theory of culture", in Geertz, C. (Ed.), The Interpretation of Cultures, New York: Basic Books.

Goulding, C. (2005), “Grounded theory, ethnography and phenomenology: A comparative analysis of three qualitative strategies for marketing research", European Journal of Marketing, Vol. 39 Nos. 3/4, pp. 294-308.

Goulding, C., Shankar, A. and Canniford, R. (2010), "Learning to be tribal: facilitating the formation of consumer tribes", European Journal of Marketing, Vol. 47 No. 5/6, pp. 813-32.

Gummesson, E. (2000), Qualitative Methods in Management Research (2 ${ }^{\text {nd }}$ ed.), Sage, Thousand Oaks, CA. 
Gummesson, E. (2001), “Are current research approaches in marketing leading us astray?”, Marketing Theory, Vol. 1 No. 1, pp. 27-48.

Hackley, C.E. (1999), "Tacit knowledge and the epistemology of expertise in strategic marketing management”, European Journal of Marketing, Vol. 33 No. 7/8, pp. 72035.

Hackley, C.E. (2009), "Parallel universes and disciplinary space: The bifurcation of managerialism and social science in marketing studies", Journal of Marketing Management, Vol. 25 No. 7/8, pp. 643-59.

Hackley, C.E. and Skålén, P. (2011), "Marketing-as-practice: Introduction to the special issue”, Scandinavian Journal of Management, Vol. 27 No. 2, pp. 189-96.

Heilman, E. (2003), "Critical theory as a personal project: From early idealism to academic realism", Educational Theory, Vol. 53 No. 3, pp. 247-74.

Holbrook, M.B. (1985), "Why business is bad for consumer research: The three bears revisited", in Hirschman, E.C. and Holbrook, M.B. (Eds.), Advances in Consumer Research, Provo UT: Association for Consumer Research, pp. 145-56.

Humm, M. (1995), The Dictionary of Feminist Theory, $2^{\text {nd }}$ ed., Hemel Hempstead: Harvester Wheatsheaf. 
Katsikeas, C.S., Robson, M.J. and Hulbert, J. M. (2004), "In search of relevance and rigour for research in marketing, Marketing Intelligence and Planning, Vol. 22 No. 5, 56878.

Lakoff, G. and Johnson, M. (1999), Philosophy in the Flesh: The Embodied Mind and its Challenge to Western Thought, Basic Books, New York.

Lee, N. and Greenley, G. (2010), "The theory-practice divide: thoughts from the editors and senior advisory board of EJM", European Journal of Marketing, Vol. 44 No. 1/2, pp. $5-20$.

Levy, S. (2003), "Roots of marketing and consumer research", Consumption, Markets and Culture, Vol. 6 No. 2, pp. 99-110.

Lowe, S., Carr, A.N., Thomas, M. and Watkins-Mathys, L. (2005), "The fourth hermeneutic in marketing theory", Marketing Theory, Vol. 5 No. 2, pp. 185-203.

Magala, S. (2005), Cross-cultural Competence, Routledge, London.

Murchison, J. (2010), Ethnography Essentials: Designing, Conducting, and Presenting Your Research, John Wiley \& Sons.

O'Reilly, K. (2012), "Ethnographic returning, qualitative longitudinal research and the reflexive analysis of social practice", The Sociological Review, Vol. 60 No. 3, pp. 518-536. 
Patterson, A., Quinn, L. and Baron, S. (2012), “The power of intuitive thinking: a devalued heuristic of strategic marketing", Journal of Strategic Marketing, Vol. 20 No. 1, pp. $35-44$.

Patton, M.Q. (1990), Qualitative Evaluation and Research Methods, Sage, Newbury Park, C.A.

Perry, C., Riege, A. and Brown, L. (1999), “Realism's role among scientific paradigms in marketing research", Irish Marketing Review, Vol. 12 No. 2, pp. 16-23.

Polonsky, M.J. and Whitelaw, P. (2005), "What are we measuring when we evaluate journals?”, Journal of Marketing Education, Vol. 27 No. 2, pp. 189-201.

Rasche, A. and Chia, R. (2009), "Researching strategy practices: a genealogical social theory perspective”, Organization Studies, Vol. 30 No. 7, pp. 713-34.

Reibstein, D.J., Day, G. and Wind, J. (2009), “Guest editorial: Is marketing academia losing its way?", Journal of Marketing, Vol. 73, pp. 1-3.

Salipante, P. and Aram, J.D. (2003), "Managers as knowledge generators: The nature of practitioner-scholar research in the nonprofit sector", Nonprofit Management \& Leadership, Vol. 14 No. 2, pp. 129-50.

Sandberg, J. and Tsouksas, H. (2011), “Grasping the logic of practice: Theorizing through practical rationality”, Academy of Management Review, Vol. 36 No. 2, pp. 338-60. 
Schiffrin, D., Tannen, D. and Hamilton, H.E. (2001), (Eds.) The Handbook of Discourse Analysis, Blackwell Publishers, Oxford, U.K.

Schumacher, E.F. (1977), A Guide for the Perplexed, Jonathan Cape, London.

Scott, L. (2007), "Critical research in marketing: An armchair report", in Saren, M., Maclaran, P., Goulding, C., Elliott, R., Shankar, A. and Catterall, M. (Eds.), Critical Marketing: Defining the Field, Butterworth Heinemann/Elsevier, Oxford, U.K., pp. 317.

Shankar, A. (2009), "Reframing critical marketing", Journal of Marketing Management, Vol. 25 No. 7/8, pp. 681-96.

Sheth, J.N. and Sisodia, R.S. (1999), "Revisiting marketing's law-like generalisations", Journal of the Academy of Marketing Science, Vol. 27 No. 1, pp. 71-87.

Schön, D.A. (1983), The Reflective Practitioner, NY: Basic Books.

Shotter, J. (2008), "Dialogism and polyphony in organizing theorizing in organization studies: Action guiding anticipations and the continuous creation of novelty", Organization Studies, Vol. 29 No. 4, pp. 501-24.

Splitter, V. and Seidl, D. (2011), "Does practice based research on strategy lead to practically relevant knowledge? Implications of a Bourdieusian perspective", The Journal of Applied Behavioural Science, Vol. 47 No. 1, pp. 98-120. 
Stake, R.E. (2005), “Qualitative case studies”, in Denzin, N.K. and Lincoln, Y.S. (Eds.), The Sage Handbook of Qualitative Research ( $3^{\text {rd }}$ Ed.), SAGE Publication.

Triana, P. (2009), Lecturing Birds on Flying, Wiley, New York.

Van de Ven, A.H. and Johnson, P.E. (2006), "Knowledge for theory and practice", Academy of Management Review, Vol. 31 No. 4, pp. 802-21.

Wilkinson, I. and Gray, D.M. (2007), "The production and consumption of marketing theory", Australasian Marketing Journal, Vol. 15 No. 1, pp. 39-52.

Yin, R.K. (1994), Case Study Research - Design and Methods, Applied Social Research Methods Series Vol.5, $2^{\text {nd }}$ Edition, Sage, Newbury Park: CA.

Zinkham, G.M. and Hirschheim, R. (1992), "Truth in marketing theory and research: An alternative perspective", Journal of Marketing, Vol.56 No. 2, pp. 80-88. 